\title{
$\ll$ Research Note» \\ Effect of Dietary Fat and Protein on Performance, Egg Composition, Egg Solids, and Egg Quality of Hy-line W-36 Hens During Phase 1
}

\author{
Kun Yuan ${ }^{2 *}$, Guangbing Wu${ }^{1}$, Matilda M. Bryant ${ }^{1}$ and David. A. Roland, Sr. ${ }^{1}$ \\ ${ }^{1}$ Department of Poultry Science, Auburn University, Auburn, AL, 36849, USA \\ ${ }^{2}$ Department of Biological Sciences, Auburn University, Auburn, AL, 36849, USA
}

\begin{abstract}
A $4 \times 3$ factorial experiment with four dietary fat levels and three protein levels was conducted to determine the influence of dietary fat on performance, egg composition, egg solids, and egg quality of Hy-line W-36 hens at different protein levels. This experiment lasted 16 weeks. Hy-line W-36 hens $(n=1440)$ in phase 1 ( 21 weeks of age) were randomly divided into 12 treatments ( 8 replicates of 15 birds per treatment). There was no significant interaction on all parameters between protein and dietary fat. Protein had a significant effect on egg weight, egg mass, feed conversion, albumen weight, percent whole egg solids, and yolk color. Dietary fat had a linear effect on feed intake. As dietary fat increased from 0 to $3.35 \%$, feed conversion linearly improved. A further increase of dietary fat from 3.35 to $5.04 \%$ had no additional effect on feed conversion. There was no significant difference in egg specific gravity among hens fed diets supplemented with $0 \%, 1.67 \%$ and $3.35 \%$ fat levels. Increasing dietary fat from 3.35 to $5.04 \%$ significantly decreased egg specific gravity. As protein increased, albumen weight significantly increased and percent whole egg solids significantly decreased. Increasing dietary fat significantly increased percent yolk, yolk/albumen ratio and percent whole egg solids, but decreased percent albumen. Based on feed conversion and egg specific gravity, the addition of $3.35 \%$ fat might be sufficient for optimal performance and egg quality of Hy-line W-36 hens during phase 1.
\end{abstract}

Key words: dietary fat, egg composition, egg solids, egg weight, protein

J. Poult. Sci., 46: 322-327, 2009

\section{Introduction}

Small egg size during early egg production has been a problem for egg industry because it can significantly decrease profits. Egg weight is mainly affected by albumen weight, yolk weight, and shell weight. Yolk weight significantly increased as dietary energy or dietary fat increased (Wu et al., 2005), and albumen weight significantly increased as methionine or lysine intake increased (Prochaska et al., 1996; Shafer et al., 1998; Novak et al., 2004). A number of studies have been conducted to investigate the effect of dietary energy or dietary fat on egg weight of commercial Leghorns during early egg production (Summers and Leeson, 1993; Keshavarz, 1995; Keshavarz and Nakajima, 1995; Grobas et al., 1999; Harms et al., 2000; Bohnsack et al., 2002; Sohail et al., 2003; Jalal et al., 2006). However, the results of those studies have been inconsis-

Received: July 2, 2008, Accepted: April 27, 2009

Correspondence: Dr. G. Wu, Department of Poultry Science, Auburn University, Auburn, AL 36849, USA.

(E-mail: guangbingwu1@yahoo.com)

* Present address: Department of Food Quality and Safety, College of Light Industry and Food Sciences, South China University of Technology, Guangzhou, 510641, China tent. It is necessary to have better understanding on the influence of protein (amino acids) and dietary fat on egg composition to optimize egg weight during early egg production.

Liquid and dried egg production has increased during the last 10 years. Limited studies have been conducted to investigate the effect of dietary fat and protein on egg component and egg solids of Hy-line W-36 hens during phase 1 (Keshavarz and Nakajima, 1995; Grobas et al., 1999; Wu et al., 2005). Grobas et al. (1999) reported that the addition of fat significantly increased yolk weight and albumen weight. However, Wu et al. (2005) found that dietary fat significantly increased yolk weight while it had no effect on albumen weight. The present trial will provide the breaker egg industry more scientific information about the effect of dietary fat and protein (amino acids) on egg composition and egg solids.

Protein levels ranging from 16 to $19 \%$ are currently used by egg producers for hens during phase 1 . Sohail et al. (2003) reported that the inclusion of fat improved feed efficiency at higher protein levels $(19.8$ and $18.7 \%)$ but not at the lower level $(17.4 \%)$. This result suggests that the optimal dietary fat level may not be the same at different protein levels. More research needs to be con- 
Table 1. Ingredient and nutrient content of the experimental diets

\begin{tabular}{|c|c|c|c|c|c|c|c|c|c|c|c|c|}
\hline Ingredient $(\%)$ & Diet 1 & Diet 2 & Diet 3 & Diet 4 & Diet 5 & Diet 6 & Diet 7 & Diet 8 & Diet 9 & Diet 10 & Diet 11 & Diet 12 \\
\hline Corn & 59.05 & 57.23 & 55.38 & 53.54 & 62.68 & 60.86 & 59.02 & 57.17 & 65.95 & 64.12 & 62.29 & 60.44 \\
\hline Soybean meal & 29.28 & 29.42 & 29.57 & 29.72 & 25.65 & 25.80 & 25.95 & 26.09 & 22.39 & 22.54 & 22.68 & 22.83 \\
\hline $\mathrm{CaCO}_{3}$ & 6.98 & 6.98 & 6.97 & 6.97 & 6.99 & 6.99 & 6.98 & 6.98 & 7.00 & 7.00 & 6.99 & 6.99 \\
\hline Hardshell $^{1}$ & 2.00 & 2.00 & 2.00 & 2.00 & 2.00 & 2.00 & 2.00 & 2.00 & 2.00 & 2.00 & 2.00 & 2.00 \\
\hline Dicalcium phosphate & 1.68 & 1.69 & 1.70 & 1.71 & 1.70 & 1.71 & 1.72 & 1.72 & 1.72 & 1.73 & 1.73 & 1.74 \\
\hline Poultry oil & 0 & 1.67 & 3.35 & 5.04 & 0 & 1.67 & 3.35 & 5.04 & 0 & 1.67 & 3.35 & 5.04 \\
\hline $\mathrm{NaCl}$ & 0.38 & 0.38 & 0.38 & 0.38 & 0.38 & 0.38 & 0.38 & 0.38 & 0.38 & 0.38 & 0.38 & 0.38 \\
\hline Vitamin Premix ${ }^{2}$ & 0.25 & 0.25 & 0.25 & 0.25 & 0.25 & 0.25 & 0.25 & 0.25 & 0.25 & 0.25 & 0.25 & 0.25 \\
\hline Mineral premix ${ }^{3}$ & 0.25 & 0.25 & 0.25 & 0.25 & 0.25 & 0.25 & 0.25 & 0.25 & 0.25 & 0.25 & 0.25 & 0.25 \\
\hline DL-Methionine & 0.14 & 0.14 & 0.15 & 0.15 & 0.10 & 0.10 & 0.11 & 0.11 & 0.06 & 0.07 & 0.07 & 0.08 \\
\hline \multicolumn{13}{|l|}{ Calculated analysis } \\
\hline $\mathrm{CP}(\%)$ & 18.86 & 18.78 & 18.71 & 18.63 & 17.38 & 17.31 & 17.24 & 17.16 & 16.06 & 15.99 & 15.91 & 15.84 \\
\hline $\mathrm{ME}(\mathrm{kcal} / \mathrm{kg})$ & 2,719 & 2,798 & 2,877 & 2,956 & 2,754 & 2,833 & 2,912 & 2,992 & 2,786 & 2,865 & 2,944 & 3,023 \\
\hline $\mathrm{Ca}(\%)$ & 4.00 & 4.00 & 4.00 & 4.00 & 4.00 & 4.00 & 4.00 & 4.00 & 4.00 & 4.00 & 4.00 & 4.00 \\
\hline Available phosphorus (\%) & 0.42 & 0.42 & 0.42 & 0.42 & 0.42 & 0.42 & 0.42 & 0.42 & 0.42 & 0.42 & 0.42 & 0.42 \\
\hline Methionine $(\%)$ & 0.44 & 0.44 & 0.44 & 0.44 & 0.38 & 0.38 & 0.39 & 0.39 & 0.33 & 0.34 & 0.34 & 0.34 \\
\hline Metionine + Cystine $(\%)$ & 0.76 & 0.76 & 0.76 & 0.76 & 0.69 & 0.69 & 0.69 & 0.69 & 0.62 & 0.62 & 0.62 & 0.62 \\
\hline Lysine $(\%)$ & 1.02 & 1.02 & 1.02 & 1.02 & 0.92 & 0.92 & 0.92 & 0.92 & 0.83 & 0.83 & 0.83 & 0.83 \\
\hline
\end{tabular}

${ }^{1}$ Hardshell = large particle (passing US mesh \#4 and retained by US mesh \#6) $\mathrm{CaCO}_{3}$ supplied by Franklin Industrial Minerals, Lowell, Florida.

${ }^{2}$ Provided per kilogram of diet: vitamin A (as retinyl acetate), 8,000 IU; cholecalciferol, 2,200 ICU; vitamin E (as DL-a-tocopheryl acetate), $8 \mathrm{IU}$; vitamin $\mathrm{B}_{12}, 0.02 \mathrm{mg}$; riboflavin, $5.5 \mathrm{mg}$; $\mathrm{D}$-calcium pantothenic acid, $13 \mathrm{mg}$; niacin, $36 \mathrm{mg}$; choline, $500 \mathrm{mg}$; folic acid, $0.5 \mathrm{mg}$; vitamin $\mathrm{B}_{1}$ (thiamin mononitrate), $1 \mathrm{mg}$; pyridoxine, $2.2 \mathrm{mg}$; biotin, $0.05 \mathrm{mg}$; vitamin $\mathrm{K}$ (menadione sodium bisulfate complex), $2 \mathrm{mg}$.

${ }^{3}$ Provided per kilogram of diet: manganese, $65 \mathrm{mg}$; iodine, $1 \mathrm{mg}$; iron, $55 \mathrm{mg}$; copper, $6 \mathrm{mg}$; zinc, $55 \mathrm{mg}$; selenium, $0.3 \mathrm{mg}$.

ducted to confirm whether there is an interaction between protein and dietary fat in performance of hens.

The objective of this study was to determine the effect of dietary fat on performance, egg composition, egg solids, and egg quality in Hy-line W-36 hens during phase 1 at different protein levels.

\section{Material and Methods}

Four dietary fat levels $(0.00,1.67,3.35$ and $5.04 \%)$ and three protein levels (high, medium, and low) in a $4 \times 3$ factorial arrangement were used in this experiment. Ingredients and nutrient composition of experimental diets were shown in Table 1.

In this experiment, Hy-line W-36 hens $(n=1440)$ in phase 1 (21 weeks of age) were randomly divided into 12 treatments ( 8 replicates of 15 birds per treatment). This experiment lasted 16 weeks. Replicates were equally distributed into upper and lower cages to minimize cage level effect. Three hens were housed in a $40.6 \times 45.7 \mathrm{~cm}^{2}$ cage and five adjoining cages consisted of a replicate. All hens were housed in an environmentally-controlled house with temperature maintained as close to $25.6{ }^{\circ} \mathrm{C}$ as possible. However, because the experiment was conducted during winter month, the house temperature was less than $25.6^{\circ} \mathrm{C}$. The minimum temperature was $25^{\circ} \mathrm{C}$. The house had controlled ventilation and lighting $(16 \mathrm{~h} / \mathrm{d})$. All hens were supplied with feed and water ad libitum. Egg production was recorded daily, feed consumption and egg weight were recorded weekly, and egg specific gravity was recorded monthly. Egg weight and egg specific gravity were measured using all eggs produced during two consecutive days. Egg specific gravity was determined using 11 gradient saline solutions varying in specific gravity from 1.060 to 1.100 with 0.005-unit increments (Holder and Bradford, 1979). Mortality was determined daily and the feed consumption was adjusted accordingly. Body weight was obtained by weighing 3 hens per replicate at the end of the experiment. Egg mass and feed conversion ( $\mathrm{g}$ feed/g egg) were calculated from egg production, egg weight and feed consumption.

Three eggs from each replicate were collected in the middle and the end of experiment for measuring egg components. Eggs were weighed and then broken. The yolks were separated from the albumen. Before determining the yolk weight, the chalazae was removed by forceps. Each yolk was rolled on a paper towel to remove adhering albumen. The shells were cleaned of any adhering albumen and dried for 5 days. Albumen weight was calculated by subtracting the weight of yolk and shell from the whole egg weight.

Three eggs from each replicate were collected to measure whole egg solids in the middle and the end of experiment. The yolk and albumen from 3 eggs were mixed completely after egg shells were removed. Then 5-6 g of homogenate was pipetted into aluminum dish with weight recorded to $0.001 \mathrm{~g}$. The sample was dried in an oven for 24 hours at $105^{\circ} \mathrm{C}$ (AOAC, 1990) and then weighed to determine the whole egg solid percentage. Albumen and 
Table 2. Influence of protein and dietary fat on performance of Hy-line W-36 during phase 1

\begin{tabular}{|c|c|c|c|c|c|c|c|c|}
\hline $\begin{array}{l}\text { Protein } \\
(\%)\end{array}$ & $\begin{array}{c}\text { Dietary fat } \\
(\%)\end{array}$ & $\begin{array}{c}\text { Feed intake } \\
(\mathrm{g} / \mathrm{hen} \\
\text { per day) }\end{array}$ & $\begin{array}{l}\text { Egg } \\
\text { production } \\
(\%)\end{array}$ & $\begin{array}{l}\text { Egg } \\
\text { weight } \\
(\mathrm{g})\end{array}$ & $\begin{array}{l}\text { Egg mass } \\
\quad(g \text { egg } \\
\text { /hen per d })\end{array}$ & $\begin{array}{c}\text { Feed conversion } \\
\text { ( } \mathrm{g} \text { of feed } \\
\text { /of g egg) }\end{array}$ & $\begin{array}{l}\text { Body } \\
\text { weight } \\
(\mathrm{kg})\end{array}$ & $\begin{array}{c}\text { Mortality } \\
(\%)\end{array}$ \\
\hline High & & 92.12 & 87.64 & $55.95^{\mathrm{a}}$ & $49.04^{\mathrm{a}}$ & $1.88^{\mathrm{c}}$ & 1.48 & 0.21 \\
\hline Medium & & 92.38 & 87.52 & $55.74^{\mathrm{a}}$ & $48.77^{\mathrm{a}}$ & $1.90^{\mathrm{b}}$ & 1.50 & 0.62 \\
\hline Low & & 92.38 & 86.08 & $54.62^{\mathrm{b}}$ & $47.02^{\mathrm{b}}$ & $1.96^{\mathrm{a}}$ & 1.50 & 0.62 \\
\hline & 0 & $95.02^{\mathrm{a}}$ & 86.39 & 55.41 & 47.87 & $1.99^{\mathrm{a}}$ & 1.49 & 1.11 \\
\hline & 1.67 & $94.08^{\mathrm{a}}$ & 88.13 & 55.48 & 48.89 & $1.93^{\mathrm{b}}$ & 1.49 & 0.28 \\
\hline & 3.35 & $90.75^{\mathrm{b}}$ & 86.95 & 55.48 & 48.24 & $1.88^{\mathrm{c}}$ & 1.49 & 0.00 \\
\hline & 5.04 & $89.31^{\mathrm{b}}$ & 86.86 & 55.38 & 48.11 & $1.86^{\mathrm{c}}$ & 1.50 & 0.56 \\
\hline Pooled SEM & & 0.87 & 1.40 & 0.43 & 0.73 & 0.02 & 0.03 & 0.57 \\
\hline \multicolumn{9}{|c|}{ Main effect and interaction } \\
\hline Protein & & NS & NS & 0.0001 & 0.0007 & 0.0001 & NS & NS \\
\hline Dietary fat & & 0.0001 & NS & NS & NS & 0.0001 & NS & NS \\
\hline Protein $\times$ Fat & & NS & NS & NS & NS & NS & NS & NS \\
\hline \multicolumn{9}{|l|}{ Contrast } \\
\hline Fat linear & & 0.0001 & NS & NS & NS & 0.0001 & NS & NS \\
\hline Fat quadratic & & NS & NS & NS & NS & NS & NS & NS \\
\hline
\end{tabular}

${ }^{\text {a-c }}$ Means within a column and under each main effect with no common superscripts differ significantly.

yolk solids were measured by using three eggs from each replicate in the middle and the end of experiment. After yolks were separated from albumens, three yolks or albumens from each replicate were mixed together, separately. The procedure for analyzing albumen and yolk solid percentage was the same as that for total egg solid percentage. Yolk color and Haugh unit were measured (3 eggs of each replicate) at the end of experiment by egg multi-tester EMT-5200 (Robotmation, Co., Ltd, Japan).

Data were analyzed by proc mixed procedures of Statistical Analysis System (SAS Institute, 2000) for a randomized complete block with a factorial treatment design. Dietary fat and protein were fixed, while blocks were random. The factorial treatment arrangement consisted of 4 dietary fat levels and 3 protein levels. The following model used to analyze data was as follows:

$$
\mathbf{Y}_{\mathrm{ijk}}=\mu+\alpha_{\mathrm{i}}+\beta_{\mathrm{j}}+(\alpha \beta)_{\mathrm{ij}}+\mathbf{P}_{\mathrm{k}}+\varepsilon_{\mathrm{ijk}},
$$

Where $\mathrm{Y}_{\mathrm{ijk}}=$ individual observation, $\mu=$ experimental mean, $\alpha_{\mathrm{i}}=$ dietary fat effect, $\beta_{\mathrm{j}}=$ protein effect, $(\alpha \beta)_{\mathrm{ij}}=$ interaction between dietary fat and protein, $\mathbf{P}_{\mathrm{k}}=$ effect of block, $\varepsilon_{\mathrm{ijk}}=$ error component. If differences in treatment means were detected by ANOVA, Duncan's Multiple Range Test was applied to separate means. Contrast statements were utilized to test for linear or quadratic dietary fat effects. A significance level of $P \leq 0.05$ was used during analysis.

\section{Results and Discussion}

There was no significant interaction on all parameters between protein and dietary fat. Protein had no significant effect on feed intake (Table 2). The addition of fat had a linear effect on feed intake at all three protein levels. As dietary fat increased from 0 to $5.04 \%$, feed intake linearly decreased from 95.02 to $89.31 \mathrm{~g} /$ hen per day, which results in a $6 \%$ decrease of feed intake.

There was no significant protein effect on egg production (Table 2). Increasing protein had a linear effect on egg weight and egg mass. Addition of fat had no significant effect on egg production, egg weight, and egg mass. When protein level increased, feed conversion significantly improved (Table 2). Neither protein nor dietary fat had a significant effect on body weight and mortality.

As protein level increased, nutrient (protein, TSAA and lysine) intake for $1 \mathrm{~g}$ egg linearly increased and energy intake for $1 \mathrm{~g}$ egg linearly decreased (Table 3 ). The addition of fat significantly decreased protein, TSAA and lysine intake for $1 \mathrm{~g}$ egg, but had no effect on energy intake for $1 \mathrm{~g}$ egg (Table 3 ). With increasing dietary fat hens adjusted feed intake from 95.02 to $89.31 \mathrm{~g} /$ hen per $\mathrm{d}$ to achieve a constant energy intake so that the same amount of dietary energy $(5.5 \mathrm{kcal})$ were consumed to produce 1 g egg (Table 3).

Protein had no significant effect on yolk weight, shell weight, percent yolk, percent albumen, percent shell, and yolk/albumen ratio (Table 4). Addition of fat had no effect on yolk weight, albumen weight, shell weight and percent shell. As dietary fat increased from 0 to 5.04\%, percent yolk linearly increased and percent albumen linearly decreased, resulting in increased yolk/albumen ratio (Table 4).

As protein increased, percent whole egg solids linearly decreased (Table 5). Increasing dietary fat linearly increased percent whole egg solids. Either protein or dietary fat had no effect on percent yolk solids and percent albumen solids. As protein increased, yolk color linearly decreased from 6.28 to 5.83 (Table 5). Either protein or 
Table 3. Influence of protein and dietary fat on nutrient intake for one gram eggs of Hy-line W-36 during phase 1

\begin{tabular}{|c|c|c|c|c|c|}
\hline \multirow{2}{*}{$\begin{array}{l}\text { Protein } \\
(\%)\end{array}$} & \multirow{2}{*}{$\begin{array}{c}\text { Dietary fat } \\
(\%)\end{array}$} & \multicolumn{4}{|c|}{ Nutrients used to produce $1 \mathrm{~g}$ egg } \\
\hline & & Dietary Energy (kcal) & Protein (g) & TSAA (mg) & Lysine (mg) \\
\hline High & & $5.3^{\mathrm{c}}$ & $0.35^{\mathrm{a}}$ & $14.27^{\mathrm{a}}$ & $19.17^{\mathrm{a}}$ \\
\hline Medium & & $5.4^{\mathrm{b}}$ & $0.33^{\mathrm{b}}$ & $13.06^{\mathrm{b}}$ & $17.43^{\mathrm{b}}$ \\
\hline Low & & $5.7^{\mathrm{a}}$ & $0.31^{\mathrm{c}}$ & $12.18^{\mathrm{c}}$ & $16.31^{\mathrm{c}}$ \\
\hline & 0 & 5.5 & $0.35^{\mathrm{a}}$ & $13.70^{\mathrm{a}}$ & $18.34^{\mathrm{a}}$ \\
\hline & 1.67 & 5.5 & $0.33^{\mathrm{b}}$ & $13.27^{\mathrm{b}}$ & $17.75^{\mathrm{b}}$ \\
\hline & 3.35 & 5.5 & $0.32^{\mathrm{c}}$ & $12.98^{\mathrm{c}}$ & $17.35^{\mathrm{c}}$ \\
\hline & 5.04 & 5.5 & $0.32^{\mathrm{c}}$ & $12.82^{\mathrm{c}}$ & $17.15^{\mathrm{c}}$ \\
\hline Pooled SEM & & 0.05 & 0.003 & 0.13 & 0.17 \\
\hline \multicolumn{6}{|c|}{ Main effect and interaction } \\
\hline Protein & & 0.0016 & 0.0001 & 0.0001 & 0.0001 \\
\hline Dietary fat & & 0.0613 & 0.0001 & 0.0001 & 0.0001 \\
\hline Protein $\times$ Fat & & NS & NS & NS & NS \\
\hline \multicolumn{6}{|l|}{ Contrast } \\
\hline Fat linear & & 0.0459 & 0.0001 & 0.0001 & 0.0001 \\
\hline Fat quadratic & & NS & NS & NS & NS \\
\hline
\end{tabular}

${ }^{\mathrm{a}-\mathrm{c}}$ Means within a column and under each main effect with no common superscripts differ significantly.

Table 4. Influence of protein and dietary fat on egg component of $\mathrm{Hy}$-line W-36 during phase $\mathbf{1}$

\begin{tabular}{|c|c|c|c|c|c|c|c|c|}
\hline \multirow{2}{*}{$\begin{array}{l}\text { Protein } \\
(\%)\end{array}$} & \multirow{2}{*}{$\begin{array}{c}\text { Dietary fat } \\
(\%)\end{array}$} & \multicolumn{3}{|c|}{ Egg component weight (g) } & \multicolumn{3}{|c|}{$\%$ of egg component } & \multirow{2}{*}{$\begin{array}{c}\text { Yolk/albumen } \\
\text { ratio }\end{array}$} \\
\hline & & Yolk & Albumen & Shell & Yolk & Albumen & Shell & \\
\hline High & & 14.6 & $36.5^{\mathrm{a}}$ & 4.9 & 26.0 & 65.2 & 8.7 & 0.399 \\
\hline Medium & & 14.6 & $36.2^{\mathrm{a}}$ & 4.9 & 26.3 & 65.0 & 8.7 & 0.404 \\
\hline \multirow[t]{5}{*}{ Low } & & 14.4 & $35.4^{\mathrm{b}}$ & 4.8 & 26.4 & 64.8 & 8.8 & 0.408 \\
\hline & 0 & 14.3 & 36.2 & 4.8 & $25.8^{\mathrm{b}}$ & $65.4^{\mathrm{a}}$ & 8.8 & $0.395^{\mathrm{b}}$ \\
\hline & 1.67 & 14.4 & 36.2 & 4.8 & $26.0^{\mathrm{b}}$ & $65.2^{\mathrm{ab}}$ & 8.7 & $0.399^{\mathrm{b}}$ \\
\hline & 3.35 & 14.6 & 36.0 & 4.9 & $26.4^{\mathrm{ab}}$ & $64.9^{\mathrm{bc}}$ & 8.8 & $0.406^{\mathrm{ab}}$ \\
\hline & 5.04 & 14.8 & 35.7 & 4.9 & $26.8^{\mathrm{a}}$ & $64.5^{\mathrm{c}}$ & 8.8 & $0.415^{\mathrm{a}}$ \\
\hline \multirow[t]{2}{*}{ Pooled SEM } & & 0.20 & 0.25 & 0.07 & 0.31 & 0.32 & 0.12 & 0.011 \\
\hline & & 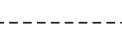 & 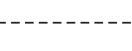 & - & Probabili & 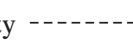 & & . \\
\hline \multicolumn{9}{|c|}{ Main effect and interaction } \\
\hline Protein & & NS & 0.0001 & NS & NS & NS & NS & NS \\
\hline Dietary fat & & 0.0933 & NS & NS & 0.0017 & 0.0040 & NS & 0.0018 \\
\hline Protein $\times$ Fat & & NS & NS & NS & NS & NS & NS & NS \\
\hline \multicolumn{9}{|l|}{ Contrast } \\
\hline Fat linear & & 0.0122 & 0.0477 & NS & 0.0001 & 0.0003 & NS & 0.0002 \\
\hline Fat quadratic & & NS & NS & NS & NS & NS & NS & NS \\
\hline
\end{tabular}

${ }^{\mathrm{a}-\mathrm{c}}$ Means within a column and under each main effect with no common superscripts differ significantly.

dietary fat had no influence on Haugh unit.

Increasing protein level significantly increased egg weight (Table 2). This result was in agreement with that of Liu et al. (2005), who reported that protein had a significant effect on egg weight. As protein increased, albumen weight linearly increased, but yolk weight and shell weight did not change. The increased egg weight was mainly due to the increased albumen weight (Table 4). Prochaska et al. (1996), Shafer et al. (1998) and Novak et al. (2004) reported that the increase of amino acid (lysine or methionine) intake per hen daily had a significant influence on albumen weight or percent albumen. These results suggested that increasing nutrient (protein, TSAA, or lysine) intake may increase albumen weight, resulting 
Table 5. Influence of protein and dietary fat on egg solids and egg quality of Hy-line W-36 during phase 1

\begin{tabular}{|c|c|c|c|c|c|c|c|}
\hline \multirow{2}{*}{$\begin{array}{c}\text { Protein } \\
(\%)\end{array}$} & \multirow{2}{*}{$\begin{array}{l}\text { Dietary fat } \\
(\%)\end{array}$} & \multicolumn{3}{|c|}{$\%$ of egg solids } & \multicolumn{3}{|c|}{ Egg quality } \\
\hline & & Whole egg & Yolk & Albumen & Egg specific gravity (unit) & Yolk color & Haugh unit \\
\hline High & & $23.67^{\mathrm{b}}$ & 50.56 & 12.60 & 1.0837 & $5.83^{\mathrm{b}}$ & 74.00 \\
\hline Medium & & $24.11^{\mathrm{a}}$ & 50.44 & 12.67 & 1.0835 & $6.11^{\mathrm{a}}$ & 75.40 \\
\hline \multirow[t]{5}{*}{ Low } & & $24.03^{\mathrm{a}}$ & 50.33 & 12.62 & 1.0834 & $6.28^{\mathrm{a}}$ & 76.74 \\
\hline & 0 & $23.73^{\mathrm{b}}$ & 50.49 & 12.74 & $1.0837^{\mathrm{a}}$ & 5.99 & 75.97 \\
\hline & 1.67 & $23.99^{\mathrm{a}}$ & 50.57 & 12.66 & $1.0838^{\mathrm{a}}$ & 6.03 & 75.91 \\
\hline & 3.35 & $23.95^{\mathrm{a}}$ & 50.48 & 12.65 & $1.0836^{\mathrm{a}}$ & 6.18 & 74.80 \\
\hline & 5.04 & $24.07^{\mathrm{a}}$ & 50.25 & 12.48 & $1.0830^{\mathrm{b}}$ & 6.11 & 74.84 \\
\hline Pooled SEM & & 0.10 & 0.26 & 0.23 & 0.0004 & 0.18 & 2.37 \\
\hline \multicolumn{8}{|l|}{ Probability } \\
\hline \multicolumn{8}{|c|}{ Main effect and interaction } \\
\hline Protein & & 0.0001 & NS & NS & NS & 0.0020 & NS \\
\hline Dietary fat & & 0.0012 & NS & NS & 0.0064 & NS & NS \\
\hline Protein $\times$ Fat & & NS & NS & NS & NS & NS & NS \\
\hline \multicolumn{8}{|l|}{ Contrast } \\
\hline Fat linear & & 0.0005 & NS & NS & 0.0025 & NS & NS \\
\hline Fat quadratic & & NS & NS & NS & NS & NS & NS \\
\hline
\end{tabular}

${ }^{\mathrm{a}-\mathrm{c}}$ Means within a column and under each main effect with no common superscripts differ significantly.

in an increase of egg weight.

As dietary fat increased from 0 to $5.04 \%$, yolk weight numerically increased from 14.3 to $14.8 \mathrm{~g}(P<0.0933)$ and percent yolk significantly increased from 25.8 to $26.8 \%$ (Table 4). Similarly, Wu et al. (2005) reported there was a linear response of yolk weight to increased dietary fat in Bovans and Dekalb hens during early egg production. Sell et al. (1987) reported that young hens can use available exogenous fat as lipid for egg yolk formation because hepatic synthesis of lipoprotein by hens is insufficient during early egg production. Hens could deposit dietary lipid into egg yolk so as to change the composition of yolk lipid (Scheideler and Froning, 1996; Scheideler et al., 1998).

As dietary fat increased from 0 to $3.35 \%$, feed conversion linearly improved. However, the further increase of dietary fat from 3.35 to $5.04 \%$ had no effect on feed conversion (Table 2). There was no significant difference in egg specific gravity among hens fed diets supplemented with $0 \%, 1.67 \%$, and $3.35 \%$ fat levels (Table 5). Hens fed the diets supplemented with 5.04\% fat level had significantly lower egg specific gravity than hens fed the diets supplemented with other three fat levels. Therefore, the addition of $3.35 \%$ fat could obtain optimal performance and egg quality in Hy-line W-36 hens during phase 1. As dietary fat increased from 0 to $5.04 \%$, percent whole egg solids linearly increased from 23.73 to $24.07 \%$. The addition of fat may be beneficial for the breaker egg industry to produce dried egg solids.

\section{References}

AOAC. Official Methods of Analysis. 15 $5^{\text {th }}$ ed. Association of Official Analysis Chemists, Washington, DC, USA. 1990.
Bohnsack CR, Harms RH, Merkel WD and Russell GB. Performance of commercial layers when fed diets with four contents of corn oil or poultry fat. Journal of Applied Poultry Research, 11: 68-76. 2002.

Grobas S, Mendez J, De Blas C and Mateos GG. Laying hen productivity as affected by energy, supplemental fat, and linoleic acid concentration of the diet. Poultry Science, 78: 1542-1551. 1999.

Harms RH, Russell GB and Sloan DR. Performance of four strains of commercial layers with major changes in dietary energy. Journal of Applied Poultry Research, 9: 535-541. 2000.

Holder DP and Bradford MV. Relationship of specific gravity of chicken eggs to number of cracked eggs and percent shell. Poultry Science, 58: 250-251. 1979.

Jalal MA, Scheideler SE and Marx D. Effect of bird cage space and dietary metabolizable energy level on production parameters in laying hens. Poultry Science, 85: 306-311. 2006.

Keshavarz K. Further investigations on the effect of dietary manipulations of nutrients on early egg weight. Poultry Science, 74: 62-74. 1995.

Keshavarz K and Nakajima S. The effect of dietary manipulations of energy, protein, and fat during the growing and laying periods on early egg weight and egg components. Poultry Science, 74: 50-61. 1995.

Liu Z, Wu G, Bryant MM and Roland DASr. Influence of added synthetic lysine in low-protein diets with the methionine plus cysteine to lysine ratio maintained at 0.75 . Journal of Applied Poultry Research, 14: 174-182. 2005.

Novak C, Yakout H and Scheideler S. The combined effects of dietary lysine and total sulfur amino acid level on egg production parameters and egg components in Dekalb Delta laying hens. Poultry Science, 83: 977-984. 2004.

Prochaska JF, Carey JB and Shafer DJ. The effect of L-lysine intake on egg component yield and composition in laying hens. Poultry Science, 75: 1268-1277. 1996. 
SAS Institute. SAS/STAT User's Guide. SAS Institute Inc., Cary, NC. 2000.

Scheideler SE and Froning GW. The combined influence of dietary flaxseed variety, level, form, and storage conditions on egg production and composition among vitamin Esupplemented hens. Poultry Science, 75: 1221-1226. 1996.

Scheideler SE, Jaroni D and Froning G. Strain and age effects on egg composition from hens fed diets rich in n-3 fatty acids. Poultry Science, 77: 192-196. 1998.

Shafer DJ, Carey JB, Prochaska JF and Sams AR. Dietary methionine intake effects on egg component yield, composition, functionality and texture profile analysis. Poultry Sci- ence, 77: 1056-1062. 1998.

Sell JL, Angel R and Escribano F. Influence of supplemental fat on weights of eggs and yolks during early egg production. Poultry Science, 66: 1807-1812. 1987.

Sohail SS, Bryant MM and Roland DASr. Influence of dietary fat on economic returns of commercial Leghorns. Journal of Applied Poultry Research, 12: 356-361. 2003.

Wu G, Bryant MM, Voitle RA and Roland DASr. Effect of dietary energy on performance and egg composition of Bovans White and Dekalb White hens during phase 1. Poultry Science, 84: 1610-1615. 2005. 